•研究报告・

\title{
洞庭湖区麇鹿再野化初期秋冬季生境选择
}

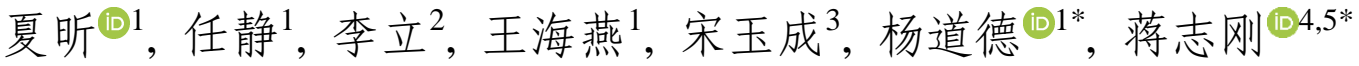

1. 中南林业科技大学野生动植物保护研究所, 长沙 410004; 2. 湖南省野生动物救护繁殖中心, 长沙 410116; 3. 湖南东洞庭湖国家级自然 保护区管理局, 湖南岳阳 414000; 4. 中国科学院动物研究所动物生态与保护生物学重点实验室, 北京 100101; 5. 中国科学院大学生命科学 学院, 北京 100049

摘要: 深入了解生境特征和生境选择的季节性差异是开展野生动物生境有效管理的前提。2016年3月, 原国家林业局和湖南 省人民政府启动了麇鹿(Elaphurus davidianus)再野化项目，来自江苏大丰的16头麇鹿(其中11头安装了 GPS卫星跟踪颈圈)在 湖南东洞庭湖国家级自然保护区君山后湖放归野外。冬季气候寒冷、食物匮乏, 濒危物种个体野放后能否在冬季找到适宜生 境是再野化项目能否成功的关键。2016年10月至2017年1月, 借助GPS卫星和地面跟踪信息, 我们采用样方法对再野化鹿鹿种 群秋、冬季生境选择进行了研究, 测定了生境类型、食物丰富度、草本盖度、乔木盖度、距水源距离、距道路距离、距居民 点距离、距隐蔽物距离、隐蔽级等9种生境因子。结果显示: (1)再野化麇鹿种群在秋、冬季对生境类型的选择差异极显著。 冬季麇鹿偏好选择水塘、随机利用草本沼泽、避免利用灌草从; 而秋季对生境类型无明显偏好。(2)再野化鹿鹿秋冬季对食物 丰富度、草本盖度、乔木盖度、距道路距离、距居民点距离、距隐蔽物距离和隐蔽级的选择差异极显著; 仅在距水源距离上 的差异不显著。(3)秋季再野化麇鹿倾向于选择隐蔽级低、食物丰富度高、草本盖度高、距隐蔽物距离近的生境。其生境利 用样方与对照样方在隐蔽级上的差异极显著; 在食物丰富度、草本盖度、距隐蔽物距离上的差异显著; 在距水源距离、乔木 盖度、距道路距离、距居民点距离上的差异不显著。(4)冬季再野化鹿鹿倾向于选择距水源近、食物丰富度高、草本盖度高 的生境。其生境利用样方与对照样方在食物丰富度、草本盖度、距水源距离上的差异极显著; 在距道路距离、距居民点距离、 距隐蔽物距离、隐蔽级上的差异不显著。研究结果揭示了洞庭湖区再野化麇鹿种群秋冬季生境选择偏好, 为再野化麇鹿种群 保护及其生境修复提供了基础数据。

关键词: 麇鹿; 再野化; 物种重引入; 生境选择; 卫星跟踪

夏昕, 任静, 李立, 王海燕, 宋玉成, 杨道德, 蒋志刚 (2021) 洞庭湖区糜鹿再野化初期秋冬季生境选择. 生物多样性, 29, 1087-1096. doi: 10.17520/biods.2021012.

Xia X, Ren J, Li L, Wang HY, Song YC, Yang DD, Jiang ZG (2021) Autumn-winter habitat selection by the re-wild Milu (Elaphurus davidianus) at the early stage after release in Dongting Lake Wetland, China. Biodiversity Science, 29, 1087-1096. doi: 10.17520/biods.2021012.

\section{Autumn-winter habitat selection by the re-wild Milu (Elaphurus davidianus) at the early stage after release in Dongting Lake Wetland, China}

\author{
Xin Xia ${ }^{(D 1}$, Jing $\operatorname{Ren}^{1}$, $\mathrm{Li} \mathrm{Li}^{2}$, Haiyan Wang${ }^{1}$, Yucheng Song ${ }^{3}$, Daode Yang ${ }^{(\mathbb{D} 1 *}$, Zhigang Jiang ${ }^{\left(\mathrm{D} 4,5^{*}\right.}$ \\ 1 Institute of Wildlife Conservation, Central South University of Forestry and Technology, Changsha 410004 \\ 2 Hunan Wildlife Rescue and Breeding Center, Changsha 410116 \\ 3 Administration of Eastern Dongting Lake National Nature Reserve, Yueyang, Hunan 414000 \\ 4 Key Laboratory of Animal Ecology and Conservation Biology, Institute of Zoology, Chinese Academy of Sciences, Beijing 100101 \\ 5 College of Life Sciences, University of Chinese Academy of Sciences, Beijing 100049
}

\section{ABSTRACT}

Purpose: For restoring the once extinct Milu (Elaphurus davidianus, Père David's deer), the wild management authority in China launched a Milu rewilding project in the Dongting Lake area, Hunan Province, China in 2016. We carried the study to investigate how the re-wild Milu select habitat in the field release area in autumn and winter.

Method: In March 2016, 16 Milu individuals (11 of them fitted with GPS collars) from the Jiangsu Dafeng Milu

收稿日期: 2021-01-09; 接受日期: 2021-05-19

基金项目: 中国科学院战略性先导科技专项子课题(XDA19050204)、国家重点研发计划(2016YFC0503303)和湖南省野生动植物保护项目(HNYB2020-002)

* 共同通讯作者 Co-authors for correspondence. E-mail: csfuyydd@126.com; jiangzg@ioz.ac.cn 
National Nature Reserve were released into the wild of Junshan Houhu in Hunan East Dongting Lake National Nature Reserve. From October 2016 to January 2017, with the aid of GPS satellite tracking and ground tracking of field released Milu, we used the quadrat method to study the autumn/winter habitat selection by the released Milu. Nine habitat variables were measured in the both Milu-used quadrats and non-used quadrats: habitat type, food abundance, herbage coverage, arbor coverage, distance to water, distance to road, distance to human settlement, distance to shelter, and hidden level.

Results: (1) There was a significant difference in the selection of habitat types by the re-wild Milu between autumn and winter. In autumn, the re-wild Milu appeared to select habitat randomly, whereas they preferred the habitats near ponds and used the herbage swamp randomly, avoiding shrub-grass habitats. (2) There were significant differences in selection for food abundance, herbage coverage, arbor coverage, distance to road, distance to human settlement, distance to shelter, and the hidden level by the re-wild Milu between autumn and winter. There was no significant difference in selection for distance to water. (3) In autumn, the re-wild Milu preferred those habitats that of lower hidden level, higher food abundance, higher herbage coverage, and closer to shelter. There was a significant difference in hidden levels between used quadrats and control (non-used) quadrats in both seasons. Additionally, there were significant differences in the selection for food abundance, herbage coverage, and distance to shelter overall. There were no significant differences in the selection of distance to water, arbor coverage, distance to road, and distance to human settlement. (4) In winter, the re-wild Milu preferred those habitats that are closer to water, with higher food abundance, or higher herbage coverage. There were significant differences in food abundance, herbage coverage, and distance to water between used quadrats and non-used quadrats, but there were no significant differences in distance to road, distance to human settlement, distance to shelter, or hidden level.

Conclusion: The study revealed the differences in habitat selection by the re-wild Milu in autumn and winter, which provide baseline data for habitat management of Milu rewilding in the wetlands of Dongting Lake.

Key words: Milu (Elaphurus davidianus); Père David's deer, rewilding; species reintroduction; habitat selection; satellite tracking

生境又称栖息地, 是生物个体能在其中完成生 长、发育、繁殖等生命过程的空间，包括所利用的 各种生态环境因子(Reunanen et al, 2002)。生境为野 生动物提供食物、饮水和隐蔽场所, 深入了解野生 动物生境特征和生境选择的季节性差异, 是开展濒 危野生动物种群科学保护及其生境有效管理的前 提(Buckley, 1997; 蒋志刚, 2004)。生境选择(habitat selection)是动物对栖息地类型的选择或偏爱(尚玉 昌, 1998), 与其种群数量、繁殖成功率以及所栖息 的生态环境等密切相关(杨忠庆等, 2004; Benson \& Chamberlain, 2007; 李宗智等, 2021)。因生理和生存 需求的不同, 野生动物在不同生活史阶段和不同时 间尺度上的生境选择存在着明显的差异(Ripple \& Beschta, 2003)。因地理生态环境的差异, 不同动物 地理种群所面临的生存压力不同, 进而导致生境选 择的主要影响因素也存在一定差异(胡杰等, 2018)。

恢复长期自我维持的自然野化濒危种群是物 种重引入的目的。如果重引入物种的栖息地要求不 能得到有效满足, 重建野化种群的最终目标就很难 实现(Nicoll et al, 2004)。麇鹿(Elaphurus davidianus) 为中国特有种、国家一级重点保护野生动物, 因
1900年八国联军入侵北京导致鹿鹿在中国境内绝 迹(曹克清, 1985; 丁玉华, 2008; 蒋志刚, 2015); 1985年我国启动了麇鹿重引入项目, 现已在北京南 海子、江苏大丰、湖北石首形成规模较大的麇鹿种 群以及全国各地近100处小种群(宋玉成, 2015; 王 立波等, 2020)。20世纪90年代, 因长江特大洪水导 致36头麇鹿从湖北石首麇鹿国家级自然保护区围 栏内逃逸, 那些逃逸鹿鹿最终在洞庭湖区形成了自 然野化种群(Yang et al, 2016)。1998年起, 通过多次 人工放归, 江苏大丰麇鹿国家级自然保护区也在黄 海滩涂建立了鹿鹿野化种群(Hu \& Jiang, 2002)。 2016年3月，原国家林业局和湖南省人民政府在洞 庭湖区启动麇鹿再野化项目。来自江苏大丰麇鹿国 家级自然保护区的 16 头鹿鹿(其中 11 头安装了 GPS 卫星跟踪仪), 在湖南东洞庭湖国家级自然保护区 的君山后湖被放归野外。麇鹿已经在圈养环境中生 存了100多年(Twigger, 2003; Jiang \& Harris, 2008); 这次鹿鹿放归是一次再野化。我们借助GPS卫星信 息对这群再野化鹿鹿进行了跟踪研究, 对其秋、冬 季生境选择进行了实地调查, 以探讨麇鹿放归野外 后对新环境的适应, 为再野化栥鹿种群保护和生境 


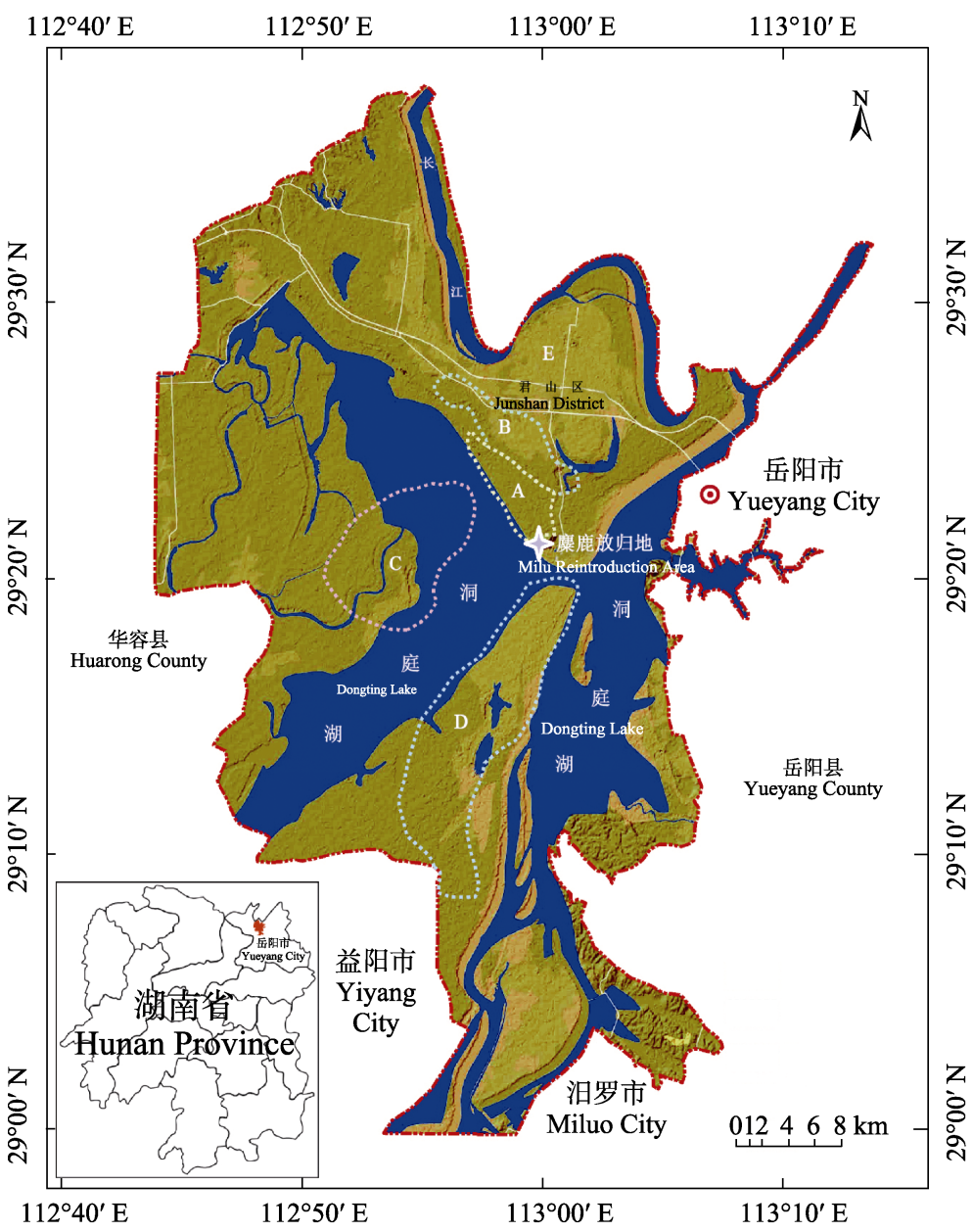

图例 Legend

A 君山后湖湿地 Junshan Houhu Wetland

B 君山大堤及以北农田区 Junshan Levee and north farmland area

$\mathrm{C}$ 注惱河湿地 Zhuzi River Wetland

D 红旗湖湿地 Hongqi Lake Wetland

$\mathrm{E}$ 湖南东洞庭湖国家级自然保护区边界线 Boundary line of East-Dongting Lake National Nature Reserve in Hunan Province

\section{图1 洞庭湖区主要研究区域示意图}

Fig. 1 Map of the main study area in Dongting Lake
管理积累基础数据。

\section{1 研究区域}

湖南东洞庭湖国家级自然保护区 $\left(29^{\circ} 00^{\prime}-\right.$ $29^{\circ} 38^{\prime} \mathrm{N}, 112^{\circ} 43^{\prime}-113^{\circ} 14^{\prime} \mathrm{E}$ )地处湖南省东北部岳 阳市境内(图1), 位于长江中下游荆江江段南侧, 面 积190,000 ha。区内气候为温和湿润、光热和风雨 充足的亚热带季风气候。年均气温 $17.0^{\circ} \mathrm{C}$ 左右, 最 热月 (7月)均温为 $29.2^{\circ} \mathrm{C}$, 而最冷月 (1月)均温为 $4.4{ }^{\circ} \mathrm{C}$ 。年降水量 $1,200-1,450 \mathrm{~mm}$, 年均日照时数约 1,600 h。全年无霜期258-275 d (周延等, 2019)。湿 地资源丰富, 类型多样。麇鹿食物资源丰富, 可食 植物达129种(杨道德, 2004)。

\section{2 研究方法}

\section{1 调查方法}

秋季调查时间为2016年10月和11月; 冬季调查 时间为2016年12月和2017年1月。每月选取无雨的
天气，采用样方法对再野化麇鹿种群开展 8-10 d的 生境选择调查。借助再野化鹿鹿佩戴的GPS颈圈的 卫星定位位点(每6 hi记录1次)和地面跟踪信息, 以 麇鹿个体发现点或活动痕迹点(粪便、足迹、卧迹、 采食痕迹等)为中心设置 $10 \mathrm{~m} \times 10 \mathrm{~m}$ 的样方(朱洪强 等, 2012), 在每个样方的中心点及四角处分别设置 $1 \mathrm{~m} \times 1 \mathrm{~m}$ 的小样方, 详细记录样方的生境类型及样 方内草本盖度、乔木盖度、食物丰富度、距水源距 离、距道路距离、距居民点距离、距隐蔽物距离和 隐蔽级等 9 种生态因子信息 $(\text { 表 } 1)^{\circledR}$ 。利用激光测距仪 (Forestry 550)或在Google Earth软件上测量距离。在 利用样方的任一方向 $100 \mathrm{~m}$ 处(避免水塘和滩涂, 且 无麇鹿活动痕迹)选取相同大小的对照样方(李言阔 等, 2008)。秋季和冬季调查的生境利用样方和对照 样方均为33个。再野化鹿鹿的活动位点见图2, 图中 位点代表麇鹿所有记录的活动位置, 部分出现在非

(1)王海燕 (2017) 洞庭湖区麇鹿野外放归初期家域和秋冬季生境选择研 究. 中南林业科技大学, 长沙. 
表1 再野化鹿鹿秋冬季生境选择相关的生态因子

Table 1 Ecological factors related to autumn-winter habitat selection by the re-wild Milu in Dongting Lake wetland

\begin{tabular}{|c|c|}
\hline 生境变量 Habitat variables & 描述 Description \\
\hline 草本盖度 Herbage coverage & 5个小样方中草本植物覆盖度的平均值 Mean of herbaceous cover in five small sampling quadrats \\
\hline 乔木盖度 Arbor coverage & 5个小样方中乔木植物覆盖度的平均值 Mean of tree canopy cover in five small sampling quadrats \\
\hline 食物丰富度 Food abundance & $\begin{array}{l}\text { 网格目测记录 } 5 \text { 个小样方中魔鹿可食植物覆盖度的平均值 The grid visually records the mean of Milu edible } \\
\text { plant cover in five small sampling quadrats }\end{array}$ \\
\hline 生境类型 Habitat type & 林地、灌草丛、草地、农田、水塘、沼泽 Woodland, shrub-grassland, grassland, farmland, ponds, herbage swamp \\
\hline 距水源距离 Distance to water & $\begin{array}{l}\text { 激光测距仪测量样方中心点与最近水源边界之间的距离 The distance between the centre of the quadrat to the } \\
\text { nearest water source measured with laser rangefinder }\end{array}$ \\
\hline 距道路距离 Distance to road & $\begin{array}{l}\text { 激光测距仪测量样方中心点与最近主干道之间的距离 The distance between the centre of the quadrat to the } \\
\text { nearest main road measured with laser rangefinder }\end{array}$ \\
\hline $\begin{array}{l}\text { 距居民点距离 } \\
\text { Distance to human settlement }\end{array}$ & $\begin{array}{l}\text { 激光测距仪测量样方中心点与最近居民点之间的距离 The distance between the centre of the quadrat to the } \\
\text { nearest settlement measured with laser rangefinder }\end{array}$ \\
\hline 距隐蔽物距离 Distance to shelte & $\begin{array}{l}\text { 激光测距仪测量样方中心点与最近隐蔽物(芦苇、乔木、土堤)之间的距离 The distance between the centre of } \\
\text { the quadrat to the nearest shelter (reed, tree, or dike) measured with laser rangefinder }\end{array}$ \\
\hline 隐蔽级 Hidden level & $\begin{array}{l}\text { 样方中心坚一根长 } 1 \mathrm{~m} \text { 的标杆, 从距样方中心的四个方向 } 20 \mathrm{~m} \text { 处记录可看到的花杆部分占总长度的百分比, } \\
\text { 取平均值 A } 1 \mathrm{~m} \text { long surveyor's pole was erected in the centre of the quadrat and the percentage of the total } \\
\text { length of the pole visible was recorded from } 20 \mathrm{~m} \text { in all four directions from the centre of the quadrat }\end{array}$ \\
\hline
\end{tabular}

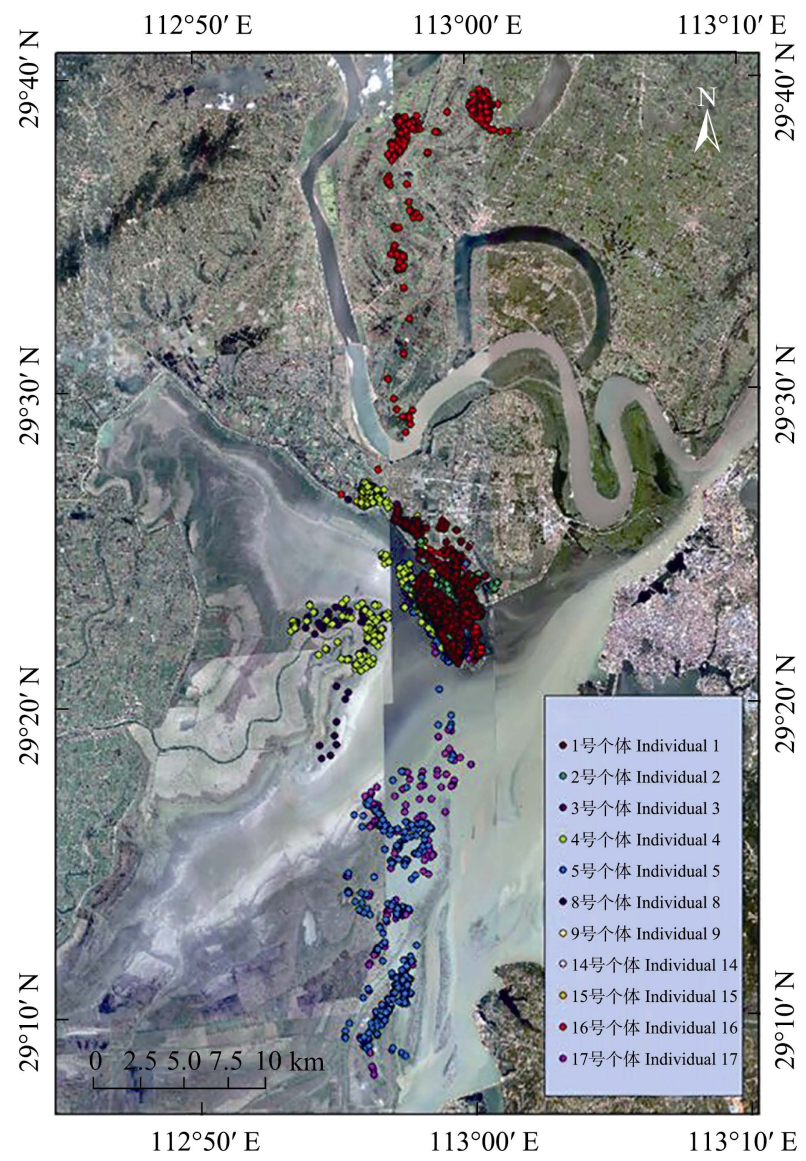

图2 洞庭湖区麇鹿再野化初期GPS卫星跟踪位点图

Fig. 2 GPS satellites tracking waypoints of Milu (Elaphurus davidianus) at its early stage of rewilding in Dongting Lake wetland

主要活动区域仅表示曾在这片区域活动。

\section{2 数据处理}

利用卡方检验法(Chi-square test)分别检验秋季 与冬季再野化鹿鹿生境类型选择的差异, 若存在显 著 $(0.01<P<0.05)$ 或极显著差异 $(P<0.01)$, 则继续 通过Bailey's置信区间法明确再野化鹿鹿种群的生 境偏好(陈龙等, 2017)。对于生态因子中的定量因子 数据, 首先用 K-S法进行正态性检验, 采用配对 $t$ 检 验对其中符合正态分布 $(P>0.05)$ 的因子进行数据 分析; 对不符合正态分布 $(P<0.05)$ 的因子则进行 Wilcoxon符号秩检验。在分析生境中定量因子数据 在秋冬两个季节间的差异时, 先进行K-S法检验和 方差同质性检验，若数据同时符合正态分布 $(P>$ $0.05)$ 和方差齐性 $(P>0.05)$, 则继续进行两个独立样 本 $t$ 检验; 若不符合, 则采用非参数估计中的两个独 立样本 Mann-Whitney U 检验。最后使用步进式 (Wilks’ lambda)判别分析法, 确定影响再野化鹿鹿 秋、冬季生境选择的关键因子。

\section{3 结果}

\section{1 秋季生境选择}

采用交叉制表卡方检验法对生境类型的统计 结果进行分析, 发现再野化麇鹿随机利用秋季生境 类型 $\left(\chi^{2}=6.616, d f=5, P=0.251>0.05\right.$, 表2)。

采用K-S检验法处理所得的各项定量生态因子 数据, 发现在再野化鹿鹿秋季生境利用样方与对照 样方中共有4组生态因子符合正态分布(表3)。对这 
表2 秋季再野化鹿鹿对生境类型的选择利用

Table 2 The habitat type preferences by the re-wild Milu in Dongting Lake wetland in autumn

\begin{tabular}{lllll}
\hline 生境类型 & 利用样方数 & 对照样方数 & 利用样方比例 & 对照样方比例 \\
Habitat type & No. of used quadrats & No. of control quadrats & Proportion of used $\left(P_{i}\right)(n=33)$ & Proportion of control $\left(P_{w}\right)(n=33)$ \\
\hline 林地 Woodland & 7 & 10 & 0.212 & 0.303 \\
灌草丛 Shrub-grassland & 6 & 3 & 0.182 & 0.091 \\
草地 Grassland & 3 & 9 & 0.091 & 0.273 \\
农田 Farmland & 14 & 9 & 0.424 & 0.273 \\
水塘 Pond & 1 & 0 & 0.030 & 0.000 \\
草本沼泽 Herbage swamp & 2 & 2 & 0.061 & 0.061 \\
\hline
\end{tabular}

表3＼cjkstart秋季再野化麇鹿利用样方与对照样方定量生态因子比较

Table 3 Comparison of quantitative ecological factors between quadrats used by the re-wild Milu and control quadrats in Dongting Lake wetland in autumn

\begin{tabular}{llllll}
\hline 生态因子 & $\begin{array}{l}\text { 利用样方 } \\
\text { Esed quadrats (mean } \pm \text { SE) }\end{array}$ & $\begin{array}{l}\text { 对照样方 } \\
\text { Control quadrats (mean } \pm \text { SE) }\end{array}$ & Z & $P$ \\
Ecological factors & $62.90 \pm 3.90$ & $48.98 \pm 4.44$ & 2.646 & - & 0.013 \\
食物丰富度 Food abundance (\%) & $69.37 \pm 4.08$ & $54.52 \pm 4.45$ & 2.690 & - & 0.011 \\
草本盖度 Herbage coverage (\%) & $9.27 \pm 3.24$ & $10.18 \pm 3.14$ & - & -0.497 & 0.619 \\
乔木盖度 Arbor coverage (\%) & $67.39 \pm 12.43$ & $88.04 \pm 17.90$ & 1.242 & - & 0.223 \\
距水源距离 Distance to water (m) & $154.45 \pm 50.57$ & $154.89 \pm 50.50$ & - & -0.417 & 0.677 \\
距道路距离 Distance to road (m) & $258.42 \pm 54.68$ & $277.52 \pm 50.20$ & - & -0.577 & 0.564 \\
距居民点距离 Distance to human settlement (m) & $20.12 \pm 8.71$ & $27.90 \pm 8.83$ & - & -2.193 & 0.028 \\
距隐蔽物距离 Distance to shelter (m) & $40.18 \pm 5.18$ & $67.55 \pm 4.13$ & -5.261 & - & 0.000 \\
隐蔽级 Hidden level (\%) & & & &
\end{tabular}

些因子进行配对样本 $t$ 检验的结果为: 秋季生境利 用样方与对照样方在隐蔽级 $(P=0.000)$ 上的差异极 显著, 在食物丰富度 $(P=0.013)$ 、草本盖度 $(P=$ $0.011)$ 上的差异显著, 在距水源距离 $(P=0.223)$ 上的 差异不显著; 对不符合正态分布的生态因子进行非 参数U检验的结果为: 生境利用样方与对照样方在 距隐蔽物距离 $(P=0.028)$ 上的差异显著, 而在乔木 盖度 $(P=0.619)$ 、距道路距离 $(P=0.677)$ 、距居民点 距离 $(P=0.564)$ 3项生态因子上的差异不显著。与对 照样方相比, 再野化糜鹿秋季倾向于选择隐蔽级较 低、食物丰富度较高、草本盖度较高、距隐蔽物距 离较近的生境。

对各项定量生态因子使用步进式方法(Wilks' lambda)进行判别分析, 结果显示有 1 个典型判别式 函数可用来区分再野化鹿鹿秋季生境利用样方与 对照样方, 该判别式的特征值为 0.363 , 正相关性系 数为 0.516 。所生成的Fisher线性判别式函数为 $\mathrm{F}_{\text {秋季 }}=$ $8.673 \times$ 乔木盖度 $+8.373 \times$ 隐蔽级 -2.777 。由此 可知, 通过乔木盖度和隐蔽级 2 项生态因子可有效 区分秋季再野化鹿鹿的生境利用样方与对照样方, 判别正确率达 $72.7 \%$ 。因Wilks' lambda检验中 $P=$
0.000 , 故此判别式函数的判别能力显著。

\section{2 冬季生境选择}

冬季所有再野化鹿鹿个体均进入湖区活动, 采 用交叉制表卡方检验法对生境类型的统计结果进 行分析, 发现冬季再野化鹿鹿对生境类型具有显著 的选择性 $\left(\chi^{2}=10.071, d f=2, P=0.007<0.01\right.$ ，表4), 偏向选择草本沼泽。

由于湖区生境内乔木盖度为 0 , 利用组与对照 组无差别, 故舍弃该项因子, 对其他生态因子进行 数据分析。采用K-S检验法处理所得的各项定量生 态因子数据, 发现在再野化麇鹿冬季生境利用样方 与对照样方的所有数据均符合正态分布(表5), 与对 照样方相比, 再野化麇鹿在冬季倾向于选择距水源 较近、食物丰富度较高、草本盖度较高的生境。

对7项定量生态因子使用步进式方法(Wilks' lambda)进行判别分析, 结果显示有 1 个典型判别式 函数可用来区分再野放麇鹿冬季生境利用样方和 对照样方，该判别式的特征值为 0.987 , 正则相关性 系数为 0.705 , 方差的累计贡献率达 $100 \%$ 。所生成的 Fisher的线性判别式函数为 $F$ 冬季 $=46.478 \times$ 草本盖 度 $-0.050 \times$ 距水源的距离 -20.237 。由此可知, 
表4 冬季再野化鹿鹿对生境类型的选择利用

Table 4 Habitat type preference by the re-wild Milu in Dongting Lake wetland in winter

\begin{tabular}{|c|c|c|c|c|}
\hline 生境类型 & 利用样方数 & 对照样方数 & 利用样方比例 & 对照样方比例 \\
\hline Habitat type & Number of used quadrats & Number of control quadrats & Proportion of used $\left(P_{i}\right)(n=33)$ & Proportion of control $\left(P_{w}\right)(n=33)$ \\
\hline 灌草丛 Shrub-grassland & 0 & 4 & 0.000 & 0.121 \\
\hline 水塘 Pond & 6 & 0 & 0.182 & 0.000 \\
\hline 草本沼泽 Herbage swamp & 27 & 29 & 0.818 & 0.879 \\
\hline
\end{tabular}

表5 冬季再野化鹿鹿利用样方与对照样方定量生态因子比较

Table 5 Comparison of quantitative ecological factors between quadrats used by the re-wild Milu and control quadrats in Dongting Lake wetland in winter

\begin{tabular}{lllll}
\hline 生态因子 & $\begin{array}{l}\text { 利用样方 } \\
\text { Used quadrats (mean } \pm \text { SE) }\end{array}$ & $\begin{array}{l}\text { 对照样方 } \\
\text { Control quadrats (mean } \pm \text { SE) }\end{array}$ & $t$ & $P$ \\
\hline Ecological factors & $86.28 \pm 2.20$ & $74.71 \pm 3.64$ & 3.359 & 0.002 \\
食物丰富度 Food abundance (\%) & $87.61 \pm 2.09$ & $79.79 \pm 2.93$ & 3.331 & 0.002 \\
草本盖度 Herbage coverage (\%) & $32.79 \pm 4.96$ & $91.96 \pm 8.38$ & -8.481 & 0.000 \\
距水源距离 Distance to water (m) & $1,150.30 \pm 80.00$ & $1,197.76 \pm 85.48$ & -1.510 & 0.141 \\
距道路距离 Distance to road (m) & $1,758.18 \pm 69.88$ & $1,786.94 \pm 70.74$ & -1.521 & 0.138 \\
距居民点距离 Distance to human settlement (m) & $120.89 \pm 13.18$ & -1.154 & 0.257 \\
距隐蔽物距离 Distance to shelter (m) & $105.71 \pm 18.78$ & $64.95 \pm 2.23$ & -0.738 & 0.466 \\
隐蔽级 Hidden level (\%) & $63.44 \pm 1.61$ & & & \\
\hline
\end{tabular}

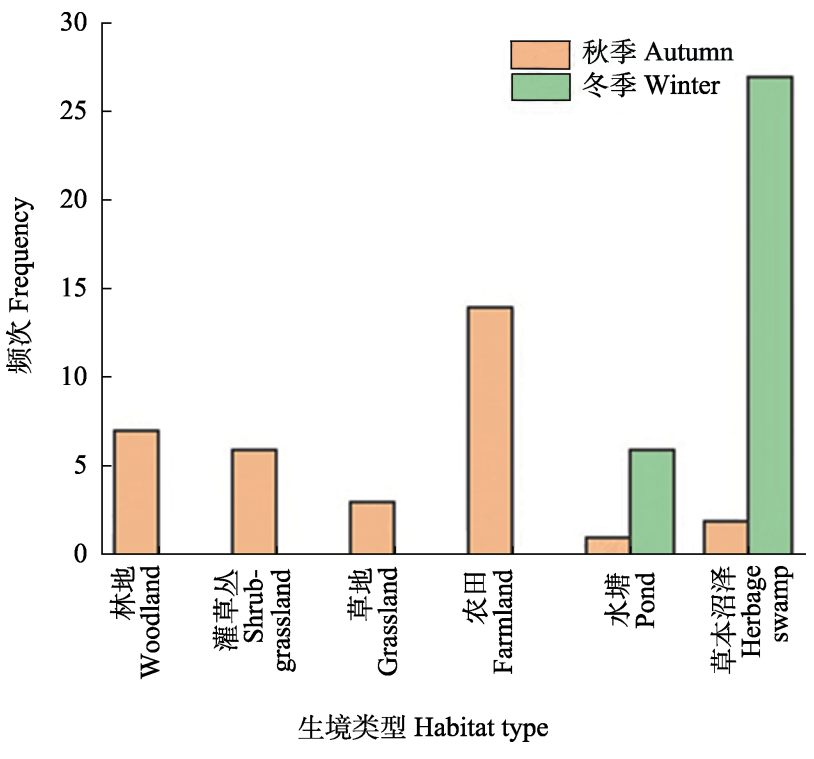

图3 再野化鹿鹿秋季与冬季生境类型利用频次

Fig. 3 Utilizing frequencies of habitat type by the re-wild Milu in Dongting Lake wetland between autumn and winter

通过草本盖度和距水源距离2项生态因子可有效区 分冬季再野放鹿鹿的利用样方与对照样方, 判别正 确率达 $83.3 \%$ 。因Wilks的lambda检验中 $P=0.000$, 故此判别式函数的判别能力显著。

\section{3 秋、冬季生境选择差异}

秋季再野化鹿鹿对生境类型无选择偏好, 而冬
季则倾向于选择草本沼泽作为其栖息地。通过对 秋、冬季生境类型的卡方检验可知, 秋、冬季再野 化麇鹿对生境类型的选择存在极显著差异 $(P=$ $0.000)$ 。在 $\chi^{2}=55.123, d f=5, P=0.000$ 时, 秋、冬季 生境类型差异表现如图3。

再野化鹿鹿秋季与冬季的生境利用存在不同 程度差异(表6): 在食物丰富度 $(P=0.000)$ 、草本盖 度 $(P=0.001)$ 、乔木盖度 $(P=0.001)$ 、距道路距离 $(P$ $=0.000)$ 、距居民点距离 $(P=0.000) 、$ 距隐蔽物距离 $(P=0.000)$ 、隐蔽级 $(P=0.001) 7$ 项因子上差异极显 著; 仅在距水源距离上差异不显著 $(P=0.077)$ 。

\section{讨论和建议}

\section{1 再野化麇鹿的生境特择}

动物生境选择的决定因素是水源、食物和隐蔽 级(Cransac \& Hewison, 1997), 而水源和食物是决 定有蹄类动物生存状况最重要的环境因子(林杰等, 2012)。生境离水源越近，越有利于动物的生存(陈化 鹏和高中信, 1992)。前期的研究表明洞庭湖区再野化 麇鹿喜欢选择近水源的草地(何振等, 2007; 贾媛媛 等, 2015), 本研究结果同样表明: 再野化鹿鹿秋、冬 季仅在距水源距离上的差异不显著, 且距离均在百 米以内, 说明了水源对于再野化鹿鹿生存的重要性。 
表6 再野化麇鹿秋、冬季生境选择的定量生态因子比较

Table 6 Comparison of quantitative ecological factors of the re-wild Milu in Dongting Lake wetland between autumn and winter

\begin{tabular}{|c|c|c|c|c|}
\hline $\begin{array}{l}\text { 生态因子 } \\
\text { Ecological factors }\end{array}$ & $\begin{array}{l}\text { 秋季 Autumn } \\
(\text { mean } \pm \mathrm{SE})\end{array}$ & $\begin{array}{l}\text { 冬季 Winter } \\
(\text { mean } \pm \mathrm{SE})\end{array}$ & $Z$ & $P$ \\
\hline $\begin{array}{l}\text { 食物丰富度 } \\
\text { Food abundance (\%) }\end{array}$ & $62.90 \pm 3.90$ & $86.28 \pm 2.20$ & -4.303 & 0.000 \\
\hline $\begin{array}{l}\text { 草本盖度 } \\
\text { Herbage coverage (\%) }\end{array}$ & $69.37 \pm 4.08$ & $87.61 \pm 2.09$ & -3.232 & 0.001 \\
\hline $\begin{array}{l}\text { 乔木盖度 } \\
\text { Arbor coverage (\%) }\end{array}$ & $9.27 \pm 3.24$ & $0.00 \pm 0.00$ & -3.392 & 0.001 \\
\hline $\begin{array}{l}\text { 距水源距离 } \\
\text { Distance to water (m) }\end{array}$ & $67.39 \pm 12.43$ & $32.79 \pm 4.96$ & -1.770 & 0.077 \\
\hline $\begin{array}{l}\text { 距道路距离 } \\
\text { Distance to road (m) }\end{array}$ & $154.45 \pm 50.57$ & $71,150.30 \pm 80.00$ & -6.362 & 0.000 \\
\hline $\begin{array}{l}\text { 距居民点距离 } \\
\text { Distance to human } \\
\text { settlement (m) }\end{array}$ & $258.42 \pm 54.68$ & $31,758.18 \pm 69.88$ & -6.740 & 0.000 \\
\hline $\begin{array}{l}\text { 距隐蔽物距离 } \\
\text { Distance to shelter (m) }\end{array}$ & $20.12 \pm 8.71$ & $105.71 \pm 18.78$ & -5.310 & 0.000 \\
\hline $\begin{array}{l}\text { 隐蔽级 } \\
\text { Hidden level (\%) }\end{array}$ & $40.18 \pm 5.18$ & $63.44 \pm 1.61$ & -3.239 & 0.001 \\
\hline
\end{tabular}

植被类型是野生动物生境中重要的隐蔽条件 (Hebblewhite et al, 2005; Torres et al, 2011)。再野化 麇鹿秋、冬季对不同生境类型的利用差异显著。秋 季再野化麇鹿随机利用各种生境类型, 因为秋后长 江水位下降, 麇鹿喜食的草本植物从丰水期被淹的 地面重新长出; 而在冬季再野化鹿鹿则对生境类型 具有显著的选择性, 主要选择在食物丰富、植被盖 度大、隐蔽度高的生境, 偏向选择草本沼泽, 避免 利用灌草从。因为灌草从高度较矮且在冬季植被盖 度较低, 无法满足麇鹿御寒和隐蔽条件的需求。因 此, 生境中灌草从成为制约再野化鹿鹿生境选择的 重要因素。这与湖北石首麇鹿冬季卧栖地微生境选 择的研究结果相似(邹师杰等, 2013)。

捕食风险和食物丰度或质量的权衡常被用以 解释有蹄类动物对生境和资源的选择 (Rettie \& Messier, 2000; Grignolio et al, 2007; Hamel \& Cote, 2007), 生境中食物可获得性是影响动物生存的重 要特征(Michel et al, 2020)。麇鹿的食物类型多样, 以禾本科和豆科等草本植物为主要食物。栖息地内 麇鹿可食及喜食植物资源短缺会制约鹿鹿种群发 展(贾媛媛等, 2015)。研究表明, 许多以草本植物为 食的野生动物在食物选择和隐蔽警戒的权衡中, 通 常改变警戒模式, 以选择食物丰富的生境, 而不选
择隐蔽条件较好、但喜好食物相对较少的生境 (Cresswell, 1994; Lima, 1995; Roberts, 1996; Dias, 2006; 游章强等, 2014)。这也是再野化鹿鹿在秋季 选择食物丰富度高而隐蔽级较低的生境的原因。

此外, 人类干扰可能导致野生动物栖息地丧失, 进而影响动物的生境选择(Luo et al, 2014)。宋玉成 (2015)指出人口密度和人类干扰是影响麇鹿扩散逃 逸的主要原因。因为洞庭湖区域的再野化鹿鹿栖息 与人为活动存在冲突, 每年秋季的收割芦苇与捡鹿 角等人为活动对鹿鹿的行为活动均造成了较大的 影响(李弛等, 2015), 因此避免再野化鹿鹿与人类活 动冲突也是首当其冲需要解决的问题。

\section{2 生境选择的时间尺度}

生境选择是一个复杂的过程, 可发生在多个水 平或尺度上, 通过开展多尺度生境选择研究, 才能 准确地把握野生动物的生境需求(张明海和李言阔, 2005)。野生动物生境选择研究的空间尺度, 可分为 微生境、家域、宏生境和景观尺度; 对于时间尺度 而言, 动物的生境选择具有时间动态(Boyce et al, 2003; Ensing et al, 2014), 生境选择可随着季节变化 而变化, 也可在一天的时间内变化(Richter et al, 2020)。目前国内外对动物生境选择的研究有单一季 节(鲁庆涁等，2007; 申定健等，2009; 葛小芳等, 2015; 李佳等, 2015)或多个季节(吴鹏举和张恩迪, 2004; 陈良等, 2010; 边坤等, 2016)。随着季节的变 化, 有蹄类动物对生境的选择也做出相应的改变, 表现在不同的生活季节里, 有蹄类呈现出较强的生 境选择性。这使得有蹄类生境选择时间动态研究显 得同样重要。再野化鹿鹿在秋、冬季进入不同的生 活史, 其生理和生存需求也不尽相同; 其表现在 距水源距离上差异最不明显。后续需结合景观尺度 开展生境选择研究, 以掌握再野化糜鹿生境选择 的内在规律。

\section{3 建议}

基于本次研究结果, 对东洞庭湖区再野化鹿鹿 种群及其生境的保护与管理工作提出以下建议: (1) 修建给排水设施, 确保水系畅通及水源质量, 保障 再野化鹿鹿饮水安全; (2)建设再野化鹿鹿监测和保 护管理站点, 实时监控、及时了解再野化鹿鹿的生 存状况; (3)修建“庇护所”, 在食物贵乏的冬季为再 野化鹿鹿提供资源和隐蔽场所。 


\section{ORCID}

夏昕 (D) https://orcid.org/0000-0002-5431-3753

杨道德 (D) https://orcid.org/0000-0002-9212-913X

蒋志刚 (D) https://orcid.org/0000-0003-2154-8588

\section{参考文献}

Benson JF, Chamberlain MJ (2007) Space use and habitat selection by female Louisiana black bears in the Tensas River Basin of Louisiana. Journal of Wildlife Management, 71, 117-126.

Bian K, Wang KF, Liu CG, Si KC, Zhu DB, Wang ZJ (2016) Habitat selection by Naemorhedus goral during summer and winter in the Zhouzhi Nature Reserve of Qinling Mountain. Chinese Journal of Ecology, 35, 1553-1560. (in Chinese with English abstract) [边坤, 王开锋, 刘楚光, 司开创, 朱 代博, 王志军 (2016) 秦岭周至自然保护区斑羚夏冬季 生境选择利用. 生态学杂志, 35, 1553-1560.]

Boyce MS, Mao JS, Merrill EH, Fortin D, Turner MG, Fryxell J, Turchin P (2003) Scale and heterogeneity in habitat selection by elk in Yellowstone National Park. Écoscience, 10, 421-431.

Buckley NJ (1997) Spatial-concentration effects and the importance of local enhancement in the evolution of colonial breeding in seabirds. The American Naturalist, 149, 1091-1112.

Cao KQ (1985) On the reasons of extinction of the wild Mi-Deer in China. Zoological Research, 6, 111-115. (in Chinese with English abstract) [曹克清 (1985) 野生麇鹿 绝灭原因的探讨. 动物学研究, 6, 111-115.]

Chen HP, Gao ZX (1992) Wildlife Ecology. Northeast Forestry University Press, Harbin. (in Chinese) [陈化鹏, 高中信 (1992) 野生动物生态学. 东北林业大学出版社, 哈尔滨.]

Chen L, Bao YX, Zhang LL, Cheng HY, Zhang JY, Zhou YQ (2010) Seasonal changes in habitat selection by black muntjac (Muntiacus crinifrons) in Jiulong Mountain Nature Reserve. Acta Ecologica Sinica, 30, 1227-1237. (in Chinese with English abstract) [陈良, 鲍毅新, 张龙龙, 程宏毅, 张 家银, 周元庆 (2010) 九龙山保护区黑鹿栖息地选择的 季节变化. 生态学报, 30, 1227-1237.]

Chen L, Li YH, Hu YM, Xiong ZP, Wu W, Li Y, Wen QC (2017) Habitat selection by roe deer (Capreolus pygargus) over winter in the Tieli Forestry Bureau of the Lesser Xing'an Mountains. Biodiversity Science, 25, 401-408. (in Chinese with English abstract) [陈龙, 李月辉, 胡远满, 熊 在平, 吴文, 李悦, 问青春 (2017) 小兴安岭铁力林业局 冬季西伯利亚狍(Capreolus pygargus)的生境选择. 生物 多样性, 25, 401-408.]

Cransac N, Hewison AJM (1997) Seasonal use and selection of habitat by mouflon (Ovis gmelini): Comparison of the sexes. Behavioural Processes, 41, 57-67.

Cresswell W (1994) Flocking is an effective anti-predation strategy in redshanks, Tringa totanus. Animal Behaviour,
47, 433-442.

Dias RI (2006) Effects of position and flock size on vigilance and foraging behaviour of the scaled dove Columbina squammata. Behavioural Processes, 73, 248-252.

Ding YH (2008) Milu Research and Management. Nanjing Normal University Press, Nanjing. (in Chinese) [丁玉华 (2008) 麇鹿研究与管理. 南京师范大学出版社, 南京.]

Ensing EP, Ciuti S, de Wijs FALM, Lentferink DH, Hoedt AT, Boyce MS, Hut RA (2014) GPS based daily activity patterns in European red deer and North American elk (Cervus elaphus): Indication for a weak circadian clock in ungulates. PLoS ONE, 9, e106997.

Ge XF, Meng FL, Wang P, Sheng Y, Wang WP, Feng JC, Xue DY, Meng XX (2015) The spring habitat selection of reindeer (Rangifer tarandus) in Great Xing'anling of China. Acta Ecologica Sinica, 35, 5000-5008. (in Chinese with English abstract) [葛小芳, 孟凡露, 王朋, 盛岩, 王卫平, 冯金朝, 薛达元, 孟秀祥 (2015) 大兴安岭驯鹿(Rangifer tarandus)的春季生境选择. 生态学报, 35, 5000-5008.]

Grignolio S, Rossi I, Bassano B, Apollonio M (2007) Predation risk as a factor affecting sexual segregation in alpine ibex. Journal of Mammalogy, 88, 1488-1497.

Hamel S, Côté SD (2007) Habitat use patterns in relation to escape terrain: Are alpine ungulate females trading off better foraging sites for safety? Canadian Journal of Zoology, 85, 933-943.

He Z, Yang DD, Ma JZ, Li PF, Jiang ZG (2007) Winter habitat selection by Milu in Shishou, Hubei. Sichuan Journal of Zoology, 26, 764-768. (in Chinese with English abstract) [何振, 杨道德, 马建章, 李鹏飞, 蒋志刚 (2007) 湖北石 首麇鹿的冬季生境选择. 四川动物, 26, 764-768.]

Hebblewhite M, Merrill EH, McDonald TL (2005) Spatial decomposition of predation risk using resource selection functions: An example in a wolf-elk predator-prey system. Oikos, 111, 101-111.

Hu HJ, Jiang ZG (2002) Experimental release of Père David's deer in Dafeng Reserve, China. Oryx, 36, 196-199.

Hu J, Yao G, Li DY, Yang ZS, Li YH (2018) Summer habitat selection of sambar deer (Rusa unicolor) in Wolong National Nature Reserve. Acta Theriologica Sinica, 38, 277-285. (in Chinese with English abstract) [胡杰, 姚刚, 黎大勇, 杨志松, 李艳红 (2018) 卧龙国家级自然保护区 水鹿夏季生境选择. 兽类学报, 38, 277-285.]

Jia YY, Yan R, Lu LL, Xie SB, Wang YZ (2015) Habitat investigation of the main living area of Dafeng Milu. Journal of Anhui Agricultural Sciences, 43(25), 114-116. (in Chinese with English abstract) [贾媛媛, 严睿, 陆立林, 解 生涁, 王亚忠 (2015) 大丰麇鹿主要生活区的生境特征 调查. 安徽农业科学, 43(25), 114-116.]

Jiang ZG (2004) Principle of Animal Behavior and Methods in Species Conservation. Science Press, Beijing. (in Chinese) [蒋志刚 (2004) 动物行为原理与物种保护方法. 科学出 版社, 北京.] 
Jiang ZG (2015) China’s Mammal Diversity and Geographic Distribution. Science Press, Beijing. (in Chinese) [蒋志刚 (2015) 中国哺乳动物多样性及地理分布. 科学出版社, 北京.]

Jiang ZG, Harris RB (2008) Elaphurus davidianus. The IUCN Red List of Threatened Species, version 2020.3. http://www.iucnredlist.org. (accessed on 2020-10-17)

Li C, Yang DD, Zhang YM, Song YC, Li PF (2015) Autumn nocturnal bed-site selection by free-ranging and re-wilding populations of Milu (Elaphurus davidianus) in Shishou County of Hubei Province, China. Chinese Journal of Ecology, 34, 2855-2860. (in Chinese with English abstract) [李弛, 杨道德, 张玉铭, 宋玉成, 李鹏飞 (2015) 湖北石 首散放麇鹿与野化麇鹿秋季夜间卧息地选择. 生态学杂 志, 34, 2855-2860.]

Li J, Li YK, Miao LJ, Xie GY, Yuan FK (2015) A comparison of autumn habitat selection of Cervus nippon and Sus scrofa in Taohongling National Nature Reserve, China. Sichuan Journal of Zoology, 34, 300-305. (in Chinese with English abstract) [李佳, 李言阔, 缪沪君, 谢光勇, 袁芳凯 (2015) 桃红岭国家级自然保护区梅花鹿和野猪秋季生境选择差 异. 四川动物, 34, 300-305.]

Li YK, Zhang MH, Jiang ZG (2008) Habitat selection by wapiti (Cervus elaphus xanthopygus) in the Wandashan Mountains based on habitat availability. Acta Ecologica Sinica, 28, 4619-4628. (in Chinese with English abstract) [李言阔, 张明海, 蒋志刚 (2008) 基于生境可获得性的 完达山地区马鹿(Cervus elaphus xanthopygus)冬季生境选 择. 生态学报, 28, 4619-4628.]

Li ZZ, Liu ZS, Mi SH, Wu JP, Teng LW (2021) Habitat selection of the Chinese water deer at Baishan Musk Deer National Nature Reserve in spring and summer. Acta Ecologica Sinica, 41, 1625-1633. (in Chinese with English abstract) [李宗智, 刘振生, 米书慧, 吴建平, 滕丽微 (2021) 白山原鹿国家级自然保护区獐春夏生境选择. 生 态学报, 41, 1625-1633.]

Lima SL (1995) Back to the basics of anti-predatory vigilance: The group-size effect. Animal Behaviour, 49, 11-20.

Lin J, Xu WX, Yang WK, Xia CJ, Liu W (2012) Habitat suitability assessment of Equus hemionus hemionus in Kalamaili Mountain Nature Reserve. Biodiversity Science, 20, 411-419. (in Chinese with English abstract) [林杰, 徐 文轩, 杨维康, 夏参军, 刘伟 (2012) 卡拉麦里山有蹄类 自然保护区蒙古野驴生境适宜性评价. 生物多样性, 20, 411-419.]

Lu QB, Yu JA, Gao X, Yang XY, Zhou Q, Zhang LB, Zhang SY (2007) Winter habitat selection of Reeves's muntjac and wild boars in the Qingliangfeng Mountains. Acta Theriologica Sinica, 27, 45-52. (in Chinese with English abstract) [鲁庆涁, 于江傲, 高欣, 杨仙玉, 周圻, 张良斌, 章叔岩 (2007) 冬季清凉峰山区小鹿和野猪的生境选择 及差异. 兽类学报, 27, 45-52.]

Luo ZH, Liu BW, Liu ST, Jiang ZG, Halbrook RS (2014)
Influences of human and livestock density on winter habitat selection of Mongolian gazelle (Procapra gutturosa). Zoological Science, 31, 20-30.

Michel ES, Gullikson BS, Brackel KL, Schaffer BA, Jenks JA, Jensen WF (2020) Habitat selection of white-tailed deer fawns and their dams in the Northern Great Plains. Mammal Research, 65, 825-833.

Nicoll MAC, Jones CG, Norris K (2004) Comparison of survival rates of captive-reared and wild-bred Mauritius kestrels (Falco punctatus) in a re-introduced population. Biological Conservation, 118, 539-548.

Rettie WJ, Messier F (2000) Hierarchical habitat selection by woodland caribou: Its relationship to limiting factors. Ecography, 23, 466-478.

Reunanen P, Monkkonen M, Nikula A (2002) Habitat requirements of the Siberian flying squirrel in northern Finland: Comparing field survey and remote sensing data. Annales Zoologici Fennici, 39, 7-20.

Richter L, Balkenhol N, Raab C, Reinecke H, Meißner M, Herzog S, Isselstein J, Signer J (2020) So close and yet so different: The importance of considering temporal dynamics to understand habitat selection. Basic and Applied Ecology, 43, 99-109.

Ripple WJ, Beschta RL (2003) Wolf reintroduction, predation risk, and cottonwood recovery in Yellowstone National Park. Forest Ecology and Management, 184, 299-313.

Roberts G (1996) Why individual vigilance declines as group size increases. Animal Behaviour, 51, 1077-1086.

Shang YC (1998) Behavioral Ecology. Peking University Press, Beijing. (in Chinese) [尚玉昌 (1998) 行为生态学. 北京大学出版社, 北京.]

Shen DJ, Zheng HX, Wang Y, Ge L, Zeng GW, Huang YC, Li KJ, Tang L (2009) Winter habitats of dwarf blue sheep (Pseudois schaeferi) and goral (Naemorhedus goral) in Batang County, Sichuan, China. Acta Ecologica Sinica, 29, 2320-2330. (in Chinese with English abstract) [申定健, 郑 合勋, 王淯, 格来, 曾国伟, 黄艺川, 李开俊, 唐伦 (2009) 四川省巴塘县矮岩羊与斑羚冬季生境比较. 生态 学报, 29, 2320-2330.]

Song YC (2015) The Research on Dispersal Behavior and Population Dynamics of Natural Re-wild Milu (Elaphurus davidianus) in the Dongting Lake Area. PhD dissertation, Central South University of Forestry and Technology, Changsha. (in Chinese with English abstract) [宋玉成 (2015) 洞庭湖区自然野化鹿鹿种群扩散机制与种群动 态. 博士学位论文, 中南林业科技大学, 长沙.]

Torres RT, Carvalho JC, Panzacchi M, Linnell J, Fonseca C (2011) Comparative use of forest habitats by roe deer and moose in a human-modified landscape in southeastern Norway during winter. Ecological Research, 26, 781-789.

Twigger R (2003) The Extinction Club. Harper Collins Publishers, New York.

Wang LB, Jiang H, An YT, Yang YZ, Yuan BD (2020) Current 
status and conservation measures for Père David's deer in China. Chinese Journal of Wildlife, 41, 806-813. (in Chinese with English abstract) [王立波, 姜慧, 安玉亭, 杨 禹治, 原宝东 (2020) 中国麇鹿种群现状分析及保护对 策探讨. 野生动物学报, 41, 806-813.]

Wu PJ, Zhang ED (2004) Habitat selection and its seasonal change of serow (Capricornis sumatraensis) in Cibagou Nature Reserve, Tibet. Acta Theriologica Sinica, 24, 6-12. (in Chinese with English abstract) [吴鹏举, 张恩迪 (2004) 西藏慈巴沟自然保护区㼱羚生境选择的季节性变化. 兽 类学报, 24, 6-12.]

Yang DD (2004) Reintroducing Père David's Deer in the Dongting Lake Region, China: History, Practice and Feasibility. PhD dissertation, Northeast Forestry University, Harbin. (in Chinese with English abstract) [杨道德 (2004) 洞庭湖区麇鹿(Elaphurus davidianus)重引入的研究: 历 史、实践、可行性. 博士学位论文, 东北林业大学, 哈尔 滨.]

Yang DD, Song YC, Ma JZ, Li PF, Zhang H, Price MRS, Li CL, Jiang ZG (2016) Stepping-stones and dispersal flow: Establishment of a meta-population of Milu (Elaphurus davidianus) through natural re-wilding. Scientific Reports, 6, 27297.

Yang ZQ, Xie JR, Gu SG (2004) Summer habitat selection and vertical distribution of the Gansu Cervus elaphus kansuensis in the Qilianshan Temple Dalong Forest Area. Journal of Hexi University, 20(5), 46-48. (in Chinese) [杨忠庆, 谢建 荣, 顾生贵 (2004) 祁连山寺大隆林区甘肃马鹿夏季生 境选择及垂直分布的研究. 河西学院学报, 20(5), 46-48.]

You ZQ, Tang ZH, Yang YB, Yang LH, Shi HY, Liu H, Gan X, Zheng TC, Jiang ZG (2014) Summer habitat selection by white-lipped deer (Cervus albirostris) in Chaqingsongduo White-lipped Deer National Nature Reserve. Acta Theriologica Sinica, 34, 46-53. (in Chinese with English abstract) [游章强, 唐中海, 杨远斌, 杨丽红, 石红艳, 刘 吴, 甘洂, 郑天才, 蒋志刚 (2014) 察青松多白唇鹿国家 级自然保护区白唇鹿对夏季生境的选择. 兽类学报, 34, 46-53.]

Zhang MH, Li YK (2005) The temporal and spatial scales in animal habitat selection research. Acta Theriologica Sinica, 25, 395-401. (in Chinese with English abstract) [张明海, 李言阔 (2005) 动物生境选择研究中的时空尺度. 兽类 学报, 25, 395-401.]

Zhou Y, Jing L, Jia YF, Lei G, Yao Y, Lü C, Chen AP, Lei GC (2019) Population dynamics of four endangered cranes and landscape patterns of habitats in the East Dongting Lake during recent 30 years. Journal of Lake Sciences, 31, 1415-1423. (in Chinese with English abstract) [周延, 靖否, 贾亦飞, 雷刚, 姚毅, 吕偲, 陈安平, 雷光春 (2019) 东 洞庭湖4种濒危鹤类近30年种群动态及栖息地景观格局 变化. 湖泊科学, 31, 1415-1423.]

Zhu HQ, Ge ZY, Mao ZX, Liu G, Chang SH, Li C, Zhang XD, Bai YG (2012) Winter habitat selection by Cervus elaphus in Huangnihe Nature Reserve. Sichuan Journal of Zoology, 31, 478-482. (in Chinese with English abstract) [朱洪强, 葛志勇, 毛之夏, 刘庚, 常素慧, 李成, 张晓东, 白玉刚 (2012) 吉林黄泥河自然保护区马鹿冬季栖息地选择. 四 川动物, 31, 478-482.]

Zou SJ, Song YC, Yang DD, Li PF (2013) Winter bed-site microhabitat selection by Père David's deer (Elaphurus davidianus) in Hubei Shishou Milu National Nature Reserve, South-central China. Chinese Journal of Ecology, 32, 899-904. (in Chinese with English abstract) [邹师杰, 宋玉成, 杨道德, 李鹏飞 (2013) 湖北石首麇鹿国家级自 然保护区麇鹿冬季卧息地微生境选择. 生态学杂志, 32, 899-904.]

(责任编委: 蒋学龙 责任编辑: 问文杰) 